\title{
Dietary fat type and level affect thyroid hormone plasma concentrations in rats
}

\section{K. Lachowicz ${ }^{1}$, I. Koszela-Piotrowska ${ }^{2}$ and D. Rosołowska-Huszcz ${ }^{1,3}$}

\author{
Warsaw University of Life Sciences (SGGW), \\ ${ }^{1}$ Department of Dietetics, Faculty of Human Nutrition and Consumer Sciences \\ Nowoursynowska 159c, 02-776 Warsaw, Poland \\ ${ }^{2}$ Nencki Institute of Experimental Biology, Department of Cellular Biochemistry \\ Pasteura 3, 02-093 Warsaw, Poland
}

(Received 10 June 2008; revised version 26 March 2009; accepted 24 June 2009)

\begin{abstract}
The objective of the study was to examine the effect of dietary fat source and level on plasma thyroid hormone concentrations. For three weeks, male Wistar rats $(n=54)$ were fed diets containing fats differing in fatty acid (FA) composition: sunflower oil predominantly containing polyunsaturated n-6 FA, group S; rich in monounsaturated FA rape seed oil, group R; and saturated FA palm oil, group P; at three levels (w/w): 5\% LF, 10\% MF, and 20\% HF. Total thyroxine levels were higher in group $\mathrm{P}$ than $\mathrm{R}$ on the LF and MF diets. The free thyroxine concentration in rats on the LF diet was higher in group R than in $\mathrm{S}$ and $\mathrm{P}$; on the MF diet, higher in group R and $\mathrm{P}$ than $\mathrm{S}$; and on the HF diet, higher in group $\mathrm{P}$ than $\mathrm{S}$. Triiodothyronine levels were influenced by fat composition only in rats fed the HF diet, being lower in group $\mathrm{S}$ than $\mathrm{P}$. The results of this study suggest that diets differing with respect to fat type and level might have opposite effects on thyroid hormone values.
\end{abstract}

KEY WORDS: thyroid, thyroxine, triiodothyronine, reverse-triiodothyronine, nutrition, fatty acids, rats

\section{INTRODUCTION}

Thyroid hormones (TH) are involved in the regulation of both anabolic and catabolic pathways of protein (Rooyackers and Sreekumaran, 1997; Clément et al., 2002), lipid (Yen, 2001) and carbohydrate (Feng et al., 2000) metabolism. The main hormone secreted by the thyroid, 3,3',5,5'tetraiodothyronine (thyroxine,

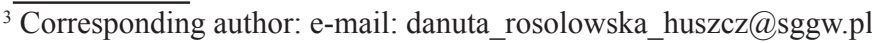


$\mathrm{T}_{4}$ ), undergoes deiodination in target tissues, either in the outer ring leading to metabolically active 3,3 ',5 triodothyronine $\left(\mathrm{T}_{3}\right)$, or in the inner ring, giving inactive 3,3',5' reverse $\mathrm{T}_{3}\left(\mathrm{rT}_{3}\right)$ (Köhrle, 2007). The metabolic effects of the TH result from the binding of $\mathrm{T}_{3}$ to specific nuclear receptors (THR) (Oetting and Yen, 2007). Excess or deficiency of TH leads to malfunctioning of the cardiovascular (Biondi and Klein, 2004), nervous (Ahmed et al., 2008) and endocrine (Mastorakos et al., 2007) systems, white and brown adipose tissues (Yen, 2001), or bones (Lakatos, 2003), and in consequence, to the impairment of homeostasis manifesting as obesity (Krotkiewski, 2002), metabolic syndrome (Lin et al., 2005), diabetes (Alrefai et al., 2002) and/or atherosclerosis (Biondi and Klein, 2004).

Nutrition, both the amount and composition of food, level of macronutrients and specific micronutrients, has been shown to affect hypothalamo-pituitary-thyroidal axis activity (Kopp, 2004). Dietary fatty acid composition has been found to influence thyrotropin (TSH) secretion (Clandinin et al., 1998), thyroid peroxidase (TPO) (Lachowicz et al., 2008), hepatic type I deiodinase (DI) activities (Kahl et al., 1998; Lachowicz et al., 2008), and $\mathrm{T}_{3}$ binding to nuclear receptors (Yamamoto et al., 2001). The combined effect of dietary fat level and composition on thyroid hormone plasma concentrations are not yet sufficiently characterized despite their importance to dietary practice. Thus, the aim of this work was to determine the response of $\mathrm{TH}$ plasma concentrations to dietary fats differing in fatty acid composition and given in low, moderate or high amounts.

\section{MATERIAL AND METHODS}

\section{Experimental design}

The experiment was conducted on 54 male Wistar rats weighing $277 \mathrm{~g}$ (SEM $4.23 \mathrm{~g}$ ) at the start of the experiment. The animals were housed individually under stable environmental conditions (illumination, 12 light: 12 dark cycle; temperature, $23^{\circ} \mathrm{C}$; air humidity, $50-65 \%$ ) with free access to feed and water.

After a two-week adaptation period, the animals were divided into 9 groups $(\mathrm{n}=6)$ and fed on diets differing in fat content $(\mathrm{w} / \mathrm{w}): 5 \%$, low fat (LF), 10\%, medium fat (MF), 20\%, high fat (HF) and fat source: sunflower oil (predominantly containing n-6 18:2 linoleic acid, group S), rape seed oil (rich in 18:1 monounsaturated oleic acid, group R), and palm oil (rich in saturated palmitic acid, group P) for three weeks. Diet compositions are given in Table 1, the fatty acid content of dietary fats, in Table 2.

At the end of the experiment the rats were sacrificed and blood was collected by cardiac puncture. Plasma was stored at $-23^{\circ} \mathrm{C}$ for hormone determination. 
The study protocol was approved by the Local Animal Care and Use Committee in Warsaw.

Table 1. Composition of experimental diets (Gronowska-Senger and Pierzynowska, 2002), g per $100 \mathrm{~g}$

\begin{tabular}{lccc}
\hline Item & Low fat, LF & Medium fat, MF & High fat, HF \\
\hline Components & 68 & & \\
$\quad$ wheat starch & 18 & 63 & 53 \\
$\quad$ casein & 5 & 18 & 18 \\
fat $^{1}$ & 5 & 10 & 20 \\
potato starch $_{\text {vitamin mixture }}^{2}$ & 1 & 5 & 5 \\
$\quad$ mineral mixture & 3 & 1 & 1 \\
choline chloride & 0.2 & 3 & 3 \\
$\quad$ gross energy, MJ per 100 g diet & 1.50 & 0.2 & 0.2 \\
Energy supplied, \% & & 1.61 & 1.82 \\
$\quad$ fat & 11.8 & & \\
$\quad$ carbohydrates & 70.8 & 22.8 & 38.5 \\
protein & 17.5 & 61.1 & 46.7 \\
\hline
\end{tabular}

${ }^{1}$ sunflower S, rape seed R and palm P oils were used; ${ }^{2}$ vitamin mixture composition per $100 \mathrm{~g}$ of mixture; IU: vit. A 200 000, vit. D 20 000, vit. E 1000; mg: vit. K 50; riboflavin 80, thiamin chloride 50, pyridoxine chloride 50, biotin 4 , vit. $\mathrm{B}_{12} 0.3$; g: PABA 1 , inosytol 1 , niacin 0.4 , calcium pantothenate $0.4 ;{ }^{3}$ mineral mixture composition per $100 \mathrm{~g}$ of mixture, g: $\mathrm{CaHPO}_{4} 73.5, \mathrm{~K}_{2} \mathrm{HPO}_{4}$ 8.1, $\mathrm{K}_{2} \mathrm{SO}_{4} 6.8, \mathrm{NaCl} 3.06, \mathrm{CaCO}_{3} 2.1, \mathrm{Na}_{2} \mathrm{HPO}_{4} 2.14, \mathrm{MgO} 2.5 ; \mathrm{mg}: \mathrm{C}_{3} \mathrm{H}_{4}(\mathrm{OH})(\mathrm{COO})_{2} \mathrm{Fe} 558$, $\mathrm{ZnCO}_{3} 81, \mathrm{MnCO}_{3} 421, \mathrm{CuCO}_{3} 33, \mathrm{C}_{3} \mathrm{H}_{4}(\mathrm{OH})(\mathrm{COOH})_{3}, 706 ; \mu \mathrm{g}: \mathrm{KJ} 720$

Table 2. Content of fatty acids and total saturated fatty acids (SFA), monounsaturated fatty acids (MUFA) and polyunsaturated fatty acids (PUFA) in dietary fats, g per $100 \mathrm{~g}$ fat

\begin{tabular}{lccc}
\hline Fatty acids & Sunflower oil & Rape seed oil & Palm oil \\
\hline C16:0 & 6.03 & 5.44 & 47.24 \\
C18:0 & 3.40 & 1.19 & 2.65 \\
ESFA & 10.50 & 6.63 & 51.89 \\
C16:1 & 0.04 & 0.00 & 2.77 \\
C18:1 n-9 & 22.18 & 62.31 & 36.08 \\
EMUFA & 23.02 & 62.85 & 43.31 \\
C18:2 n-6 & 65.91 & 25.16 & 4.07 \\
C18:3 n-3 & 0.40 & 5.36 & 0.00 \\
EPUFA & 66.31 & 30.52 & 4.07
\end{tabular}

\section{Chemical analysis}

Plasma concentrations of thyroxine, both total and free $\left(\mathrm{T}_{4}\right.$ and $\left.\mathrm{fT}_{4}\right)$, triiodothyronine $\left(\mathrm{T}_{3}\right)$, and reverse $\mathrm{T}_{3}\left(\mathrm{rT}_{3}\right)$ were determined by radioimmunoassay using commercial kits. For $\mathrm{T}_{4}$ (sensitivity $12.8 \mathrm{nmol} / \mathrm{l}$, intraassay variation $5.3 \%$, interassay variation $4.1 \%$ ) and $\mathrm{T}_{3}$ (sensitivity $0.154 \mathrm{nmol} / \mathrm{l}$, intraassay variation $3.8 \%$, interassay variation $5.4 \%$ ) the kits used were 
from POLATOM; for $\mathrm{fT}_{4}$ (sensitivity $0.8 \mathrm{pmol} / \mathrm{l}$, intraassay variation $5 \%$, interassay variation 7\%) the kit was from Orion Diagnostica, and for $\mathrm{rT}_{3}$ (sensitivity $0.014 \mathrm{nmol} / \mathrm{l}$, intraassay variation $6.5 \%$, interassay variation $7.6 \%$ ) the kit was from Biochem Immunosystems.

\section{Statistical analysis}

Statistical analysis (two-way variance ANOVA and simple regression) was performed using Statistica 6.0 software. Significant differences between groups were determined by post hoc derivation of the least significant difference between means (LSD) at the level of $\mathrm{P} \leq 0.05$. All data are expressed as means \pm SEM.

\section{RESULTS}

Body weight gain, feed energy efficiency and fatty acid intake, as well as free fatty acid: palmitic (C16:0), stearic (C18:0), oleic (C18:1), linoleic (C18:2), linolenic (C18:3), arachidonic (C20:4) and docosahexanoic (C22:6), triacyloglicerol and cholesterol concentrations in the plasma are presented in Tables 3-5.

Table 3. Body weight gain (BWG), feed intake (FI) and efficiency of energy (FE). Values expressed as the mean with standard error for six animals

\begin{tabular}{|c|c|c|c|c|c|c|c|}
\hline \multirow{3}{*}{ Variables } & \multirow{3}{*}{$\operatorname{Diets}^{1}$} & \multicolumn{6}{|c|}{ Dietary groups $^{2}$} \\
\hline & & \multicolumn{2}{|c|}{$\mathrm{S}$} & \multicolumn{2}{|c|}{$\mathrm{R}$} & \multicolumn{2}{|c|}{$P$} \\
\hline & & mean & SEM & mean & SEM & mean & SEM \\
\hline \multirow{3}{*}{$\begin{array}{l}\text { BWG } \\
\text { g/day }\end{array}$} & $\mathrm{LF}$ & $3.69^{\mathrm{aB}}$ & 0.21 & $3.03^{\mathrm{a}}$ & 0.21 & $2.71^{\mathrm{A}}$ & 0.31 \\
\hline & MF & $3.72^{\mathrm{a}}$ & 0.27 & 3.44 & 0.16 & 3.00 & 0.30 \\
\hline & $\mathrm{HF}$ & $4.98^{\mathrm{bB}}$ & 0.45 & $3.90^{\mathrm{bA}}$ & 0.29 & $3.36^{\mathrm{A}}$ & 0.14 \\
\hline \multirow{3}{*}{$\begin{array}{l}\text { FI } \\
\text { g/day }\end{array}$} & LF & 22.52 & 0.40 & 21.79 & 0.46 & 22.94 & 0.50 \\
\hline & MF & 22.90 & 0.52 & 20.89 & 0.66 & 22.23 & 0.82 \\
\hline & $\mathrm{HF}$ & 21.84 & 0.69 & 21.45 & 0.59 & 20.35 & 0.83 \\
\hline \multirow{3}{*}{$\begin{array}{l}\mathrm{FE} \\
\mathrm{g} \mathrm{BWG} / 1 \mathrm{~kJ}\end{array}$} & LF & $10.98^{\mathrm{B}}$ & 0.46 & $9.01^{\mathrm{A}}$ & 0.51 & $7.85^{\mathrm{A}}$ & 0.81 \\
\hline & MF & $9.99^{\mathrm{a}}$ & 0.53 & $10.23^{\mathrm{B}}$ & 0.78 & $8.38^{\mathrm{A}}$ & 0.74 \\
\hline & $\mathrm{HF}$ & $12.62^{\mathrm{bB}}$ & 1.12 & $9.94^{\mathrm{A}}$ & 0.31 & $9.14^{\mathrm{A}}$ & 0.49 \\
\hline
\end{tabular}

different ${ }^{\mathrm{a}, \mathrm{b}, \mathrm{c}}$ letters indicate significant differences within groups $\mathrm{S}, \mathrm{R}$ or $\mathrm{P}(\mathrm{P} \leq 0.05)$

different ${ }^{A, B, C}$ letters indicate significant differences between groups $\mathrm{S}, \mathrm{R}$ and $\mathrm{P}(\mathrm{P} \leq 0.05)$

${ }^{1,2}$ explanation see Table 1 
Table 4. Intake of fatty acids, mg per day per $100 \mathrm{~g}$ of final body weight

\begin{tabular}{|c|c|c|c|c|c|c|c|}
\hline \multirow{3}{*}{ Fatty acids } & \multirow{3}{*}{ Diets $^{1}$} & \multicolumn{6}{|c|}{ Dietary groups ${ }^{2}$} \\
\hline & & \multicolumn{2}{|l|}{$\mathrm{S}$} & \multicolumn{2}{|c|}{$\mathrm{R}$} & \multicolumn{2}{|c|}{$\mathrm{P}$} \\
\hline & & mean & SEM & mean & SEM & mean & SEM \\
\hline \multirow{3}{*}{ C16:0 } & $\mathrm{LF}$ & $18.1^{\mathrm{aA}}$ & 0.3 & $15.5^{\mathrm{aA}}$ & 0.2 & $158.9^{\mathrm{aB}}$ & 4.0 \\
\hline & MF & $39.2^{\mathrm{aA}}$ & 0.1 & $31.7^{\mathrm{aA}}$ & 1.0 & $296.7^{\mathrm{bB}}$ & 10.0 \\
\hline & $\mathrm{HF}$ & $64.6^{\mathrm{bA}}$ & 2.4 & $60.0^{\mathrm{bA}}$ & 1.7 & $498.2^{\mathrm{cB}}$ & 19.4 \\
\hline \multirow{3}{*}{ C18:0 } & $\mathrm{LF}$ & $10.2^{\mathrm{aB}}$ & 0.2 & $3.4^{\mathrm{aA}}$ & 0.0 & $8.9^{\mathrm{aB}}$ & 0.2 \\
\hline & $\mathrm{MF}$ & $22.1^{\mathrm{bC}}$ & 0.2 & $6.9^{\mathrm{bA}}$ & 0.2 & $16.6^{\mathrm{bB}}$ & 0.6 \\
\hline & $\mathrm{HF}$ & $36.4^{\mathrm{cC}}$ & 1.3 & $13.1^{\mathrm{cA}}$ & 0.4 & $27.9^{\mathrm{cB}}$ & 10.9 \\
\hline \multirow{3}{*}{ C18:1 } & $\mathrm{LF}$ & $66.4^{\mathrm{aA}}$ & 1.0 & $177.3^{\mathrm{aC}}$ & 2.2 & $121.4^{\mathrm{aB}}$ & 3.0 \\
\hline & MF & $144.0^{\mathrm{bA}}$ & 1.3 & $362.6^{\mathrm{bC}}$ & 11.1 & $226.6^{\mathrm{bB}}$ & 7.7 \\
\hline & $\mathrm{HF}$ & $237.6^{\mathrm{cA}}$ & 8.7 & $687.0^{\mathrm{cC}}$ & 19.4 & $380.5^{\mathrm{cB}}$ & 148.2 \\
\hline \multirow{3}{*}{ C18:2 } & $\mathrm{LF}$ & $197.5^{\mathrm{aC}}$ & 3.0 & $71.6^{\mathrm{aB}}$ & 0.9 & $13.7^{\mathrm{aA}}$ & 0.3 \\
\hline & MF & $428.0^{\mathrm{bC}}$ & 4.0 & $146.4^{\mathrm{bB}}$ & 4.5 & $25.6^{\mathrm{A}}$ & 0.9 \\
\hline & $\mathrm{HF}$ & $706.2^{\mathrm{cC}}$ & 25.9 & $277.4^{\mathrm{cB}}$ & 7.9 & $42.9^{\mathrm{bA}}$ & 1.7 \\
\hline \multirow{3}{*}{ C18:3 } & $\mathrm{LF}$ & $1.20^{\mathrm{aA}}$ & 0.02 & $15.25^{\mathrm{aB}}$ & 0.19 & 0.00 & 0.00 \\
\hline & MF & $2.60^{\mathrm{A}}$ & 0.02 & $31.19^{\mathrm{bB}}$ & 0.96 & 0.00 & 0.00 \\
\hline & $\mathrm{HF}$ & $4.29^{\mathrm{bA}}$ & 0.16 & $59.10^{\mathrm{cB}}$ & 1.67 & 0.00 & 0.00 \\
\hline
\end{tabular}

Thyroxine. The total thyroxine concentration (Figure 1A) was significantly affected by dietary fat composition (ANOVA; $\mathrm{P}<0.002$ ). However, this effect was seen only in rats consuming LF and MF diets, where $T_{4}$ levels were higher in group $\mathrm{P}$ than $\mathrm{S}$ and $\mathrm{R}$ in animals on the $\mathrm{LF}$ diet and higher in group $\mathrm{P}$ than $\mathrm{R}$ in rats on the MF diet. An effect of fat level on plasma $\mathrm{T}_{4}$ concentration was observed only in groups $\mathrm{S}$ and $\mathrm{R}$. In group $\mathrm{S}$, the $\mathrm{T}_{4}$ concentration was higher in animals on the MF diet than in those on diets LF and HF, which did not differ significantly. In group $\mathrm{R}, \mathrm{T}_{4}$ was higher in rats fed the HF diet than in the group receiving $\mathrm{LF}$ diets.

The plasma free $\mathrm{T}_{4}$ concentration (Figure 1B) was influenced by fat composition relative to its level (ANOVA, effect of fat composition, $\mathrm{P}<0.0001$; effect of interaction between fat level and composition, $\mathrm{P}<0.0004$ ); in rats fed the LF diet it was significantly higher in group $\mathrm{R}$ than in $\mathrm{S}$ and $\mathrm{P}$. Among rats receiving the MF diet, $\mathrm{fT}_{4}$ was higher in groups $\mathrm{R}$ and $\mathrm{P}$ than in $\mathrm{S}$, whereas in rats fed the HF diet, it was higher in group $\mathrm{P}$ than $\mathrm{S}$. In group $\mathrm{P}, \mathrm{fT}_{4}$ was lower in rats fed $\mathrm{LF}$ compared with diets MF and HF. In group $\mathrm{R}$, the $\mathrm{fT}_{4}$ concentration fell as the fat level rose, being lowest in rats receiving the HF diet. In group $\mathrm{S}$, the effect of fat level did not occur. The free $\mathrm{T}_{4}$ concentration was directly related to the levels of plasma cholesterol ( $\mathrm{r}=0.41, \mathrm{P}<0.01), \mathrm{C} 18: 1(\mathrm{r}=0.44, \mathrm{P}<0.04)$, and $\mathrm{C} 20: 4(\mathrm{r}=0.67$, $\mathrm{P}<0.0001)$. 
Table 5. Plasma FA, TAG and cholesterol concentrations

\begin{tabular}{|c|c|c|c|c|c|c|c|}
\hline \multirow{3}{*}{ Variables } & \multirow{3}{*}{ Diets $^{1}$} & \multicolumn{6}{|c|}{ Dietary groups ${ }^{2}$} \\
\hline & & \multicolumn{2}{|c|}{$\mathrm{S}$} & \multicolumn{2}{|c|}{$\mathrm{R}$} & \multicolumn{2}{|c|}{$\mathrm{P}$} \\
\hline & & mean & SEM & mean & SEM & mean & SEM \\
\hline \multirow{3}{*}{$\begin{array}{l}\mathrm{C} 16: 0 \\
\mu \mathrm{mol} / 1\end{array}$} & $\mathrm{LF}$ & $179.75^{b}$ & 35.21 & 140.60 & 34.56 & $140.00^{\mathrm{a}}$ & 31.77 \\
\hline & MF & $161.67^{b}$ & 24.83 & 109.50 & 10.93 & $153.40^{\mathrm{a}}$ & 36.09 \\
\hline & $\mathrm{HF}$ & $73.25^{\mathrm{aA}}$ & 14.82 & $113.75^{\mathrm{A}}$ & 6.00 & $268.60^{\mathrm{bB}}$ & 56.61 \\
\hline \multirow{3}{*}{$\begin{array}{l}\text { C18:0 } \\
\mu \mathrm{mol} / 1\end{array}$} & $\mathrm{LF}$ & $130.75^{\mathrm{bB}}$ & 19.35 & $47.20^{\mathrm{A}}$ & 14.55 & $50.80^{\mathrm{aA}}$ & 15.59 \\
\hline & MF & $134.50^{\mathrm{bB}}$ & 21.42 & $46.83^{\mathrm{A}}$ & 10.56 & $56.00^{\mathrm{A}}$ & 9.91 \\
\hline & $\mathrm{HF}$ & $27.25^{\mathrm{aA}}$ & 4.62 & $44.25^{\mathrm{A}}$ & 13.11 & $96.40^{\mathrm{bB}}$ & 17.58 \\
\hline \multirow{3}{*}{$\begin{array}{l}\text { C18:1 } \\
\mu \mathrm{mol} / 1\end{array}$} & $\mathrm{LF}$ & 77.75 & 33.19 & 94.25 & 64.67 & $165.60^{\mathrm{a}}$ & 54.66 \\
\hline & MF & 87.67 & 18.49 & 202.50 & 49.76 & 243.33 & 84.01 \\
\hline & $\mathrm{HF}$ & $74.67^{\mathrm{A}}$ & 22.28 & 208.00 & 35.34 & $338.33^{\mathrm{bB}}$ & 118.64 \\
\hline \multirow{3}{*}{$\begin{array}{l}\mathrm{C} 18: 2 \\
\mu \mathrm{mol} / 1\end{array}$} & $\mathrm{LF}$ & 157.50 & 43.79 & 144.33 & 38.09 & 103.20 & 46.67 \\
\hline & MF & 214.50 & 38.55 & 173.67 & 46.77 & 84.20 & 28.60 \\
\hline & $\mathrm{HF}$ & 171.00 & 70.00 & 205.25 & 40.64 & 182.00 & 61.80 \\
\hline \multirow{3}{*}{$\begin{array}{l}\mathrm{C} 18: 3 \\
\mu \mathrm{mol} / 1\end{array}$} & $\mathrm{LF}$ & 6.25 & 0.75 & $11.17^{\mathrm{a}}$ & 3.19 & 6.00 & 3.11 \\
\hline & MF & $7.33^{\mathrm{A}}$ & 3.32 & $17.33^{\mathrm{bB}}$ & 4.61 & $1.80^{\mathrm{A}}$ & 0.37 \\
\hline & $\mathrm{HF}$ & $2.33^{\mathrm{A}}$ & 0.88 & $21.00^{\mathrm{cB}}$ & 4.18 & $5.40^{\mathrm{A}}$ & 2.25 \\
\hline \multirow{3}{*}{$\begin{array}{l}\mathrm{C} 20: 4 \\
\mu \mathrm{mol} / 1\end{array}$} & $\mathrm{LF}$ & 39.67 & 10.52 & 74.83 & 19.60 & 49.40 & 12.64 \\
\hline & MF & 44.17 & 6.59 & 46.83 & 7.80 & 54.20 & 13.37 \\
\hline & $\mathrm{HF}$ & 30.00 & 6.64 & $40.50^{\mathrm{A}}$ & 7.42 & 70.60 & 16.00 \\
\hline \multirow{3}{*}{$\begin{array}{l}\mathrm{C} 22: 6 \\
\mu \mathrm{mol} / 1\end{array}$} & LF & 32.00 & 2.08 & $21.00^{\mathrm{A}}$ & 5.14 & 14.20 & 2.80 \\
\hline & MF & 22.67 & 2.82 & 17.50 & 1.84 & 15.40 & 2.23 \\
\hline & $\mathrm{HF}$ & 6.50 & 0.64 & $16.75^{\mathrm{B}}$ & 1.25 & 22.20 & 2.27 \\
\hline \multirow{3}{*}{$\begin{array}{l}\mathrm{Tg} \\
\mu \mathrm{mol} / \mathrm{l}\end{array}$} & $\mathrm{LF}$ & 1.26 & 0.11 & 1.52 & 0.16 & 1.27 & 0.16 \\
\hline & $\mathrm{MF}$ & 1.02 & 0.08 & 1.56 & 0.34 & 1.34 & 0.24 \\
\hline & $\mathrm{HF}$ & 1.14 & 0.15 & $1.27^{\mathrm{A}}$ & 0.09 & 1.78 & 0.23 \\
\hline \multirow{2}{*}{$\begin{array}{l}\text { Cholesterol } \\
\mathrm{mg} / \mathrm{dl}\end{array}$} & $\mathrm{LF}$ & 58.08 & 3.82 & 77.36 & 4.46 & 65.68 & 5.13 \\
\hline & MF & 57.73 & 3.09 & 61.50 & 8.82 & 63.48 & 8.77 \\
\hline
\end{tabular}

Triiodothyronine. The plasma concentration of triiodothyronine (Figure 2A) was not significantly altered by dietary fat composition among rats fed the LF and MF diets, but in rats receiving the HF diet the $\mathrm{T}_{3}$ level was significantly lower in group $\mathrm{S}$ than in $\mathrm{P}$. The fat level significantly influenced plasma $\mathrm{T}_{3}$ concentrations only in group $\mathrm{S}$, in which the hormone level was lower in animals on the HF diet than in those on diets MF and LF. Triiodothyronine levels were directly related to plasma $\mathrm{C} 18: 1(\mathrm{r}=0.38, \mathrm{P}<0.03), \mathrm{C} 18: 2(\mathrm{r}=0.42, \mathrm{P}<0.006)$ and $\mathrm{C} 20: 4(\mathrm{r}=0.57$, $\mathrm{P}<0.001)$ concentrations. 

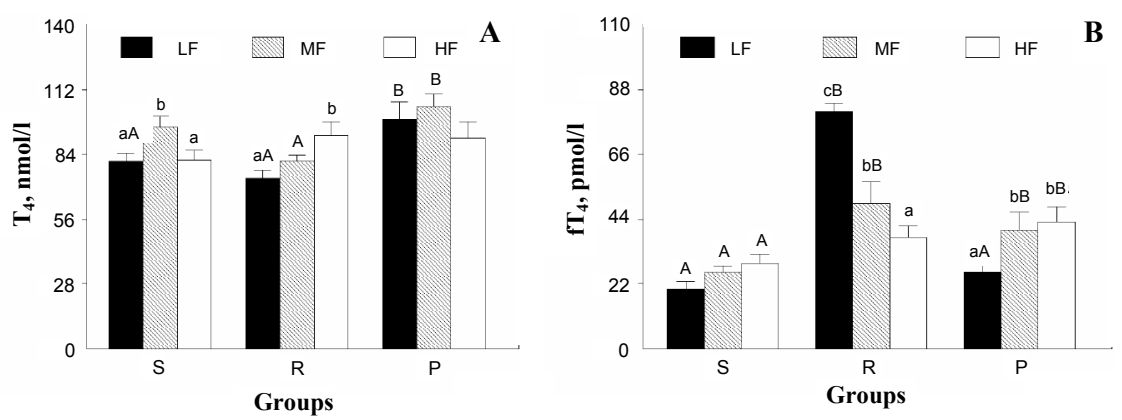

Figure 1. Plasma total thyroxine $\left(\mathrm{T}_{4}[\mathrm{nmol} / \mathrm{l}]-\right.$ panel $\left.\mathrm{A}\right)$, free thyroxine $\left(\mathrm{fT}_{4}[\mathrm{pmol} / \mathrm{l}]-\right.$ panel $\left.\mathrm{B}\right)$ concentrations in rats fed diets containing 5\% (LF), 10\% (MF) or 20\% (HF) (w/w) sunflower oil (group S), rape seed oil (group R) or palm oil (group P) for three weeks. Values are expressed as the mean with standard error for six animals; different $\mathrm{a}, \mathrm{b}$ letters indicate significant differences within groups $\mathrm{S}, \mathrm{R}$ and $\mathrm{P}(\mathrm{P} \leq 0.05)$; different $\mathrm{A}, \mathrm{B}$ letters indicate significant differences between groups $\mathrm{S}, \mathrm{R}$ and $\mathrm{P}(\mathrm{P} \leq 0.01)$
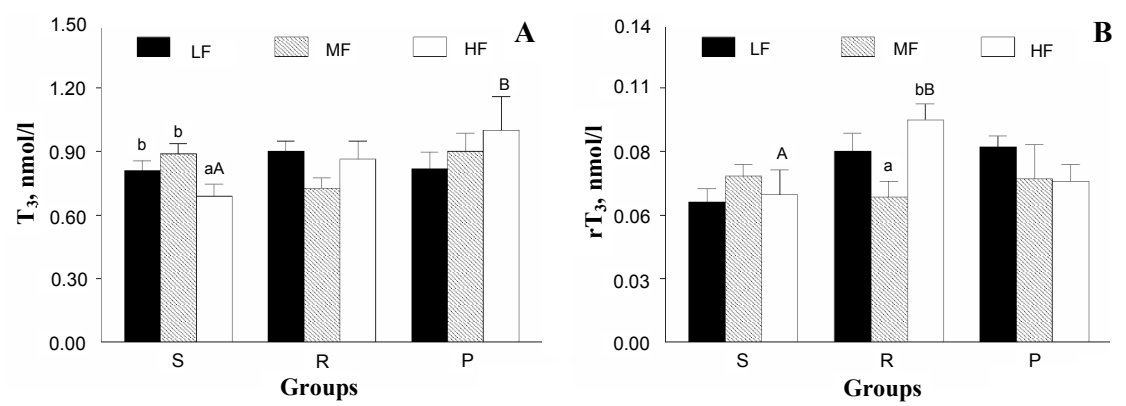

Figure 2. Plasma triiodothyronine $\left(\mathrm{T}_{3}[\mathrm{nmol} / \mathrm{l}]\right.$ - panel $\left.\mathrm{A}\right)$ and reverse triiodothyronine $\left(\mathrm{rT}_{3}[\mathrm{nmol} / \mathrm{l}]\right.$ - panel B) concentrations. Explanations see Figure 1

Reverse-triiodothyronine. According to ANOVA, the plasma concentration of reverse $\mathrm{T}_{3}$ (Figure 2B) was not significantly affected by either fat level or composition. However, in group $\mathrm{R}$, the $\mathrm{rT}_{3}$ level was higher in animals on the HF diet than in those on the MF diet, and these values were higher than in group $\mathrm{S}$ fed the HF diet. The reverse $\mathrm{T}_{3}$ level was directly related to $\mathrm{C} 18: 1$ ( $\left.\mathrm{r}=0.38, \mathrm{P}<0.001\right)$, and $\mathrm{C} 18: 3(\mathrm{r}=0.51, \mathrm{P}<0.005)$ intakes.

\section{DISCUSSION}

Plasma concentrations of $\mathrm{T}_{3}$, reverse $\mathrm{T}_{3}, \mathrm{~T}_{4}$ and $\mathrm{fT}_{4}$ responded to dietary fat level and composition in various ways. The triiodothyronine concentration was affected 
by fat level only in rats fed sunflower (S) oil. This finding partly corroborates the results of studies reporting a decrease in $\mathrm{T}_{3}$ concentration caused by high fat diets (Otten et al., 1980; Vermaak et al., 1986). However, it is difficult to explain the lack of effect of fat level on the $\mathrm{T}_{3}$ concentration in rats fed palm (P) and rape seed (R) oils. Rats in group $\mathrm{S}$ consumed the highest amounts of $n-6$ PUFA. In contrast to our results, a high fat diet rich in n-6 PUFA has previously been found to increase plasma levels of $\mathrm{T}_{3}$ and $\mathrm{T}_{4}$ compared with a high fat diet rich in n-3 PUFA and a high carbohydrate diet (Tsuboyama-Kasaoka et al., 1999). On the other hand, higher levels of $T_{3}$ and $T_{4}$ have been found in rats receiving n-3 and n-6 PUFA fatty acids compared with those fed saturated fatty acids (Takeuchi et al., 1995). Reverse $\mathrm{T}_{3}$ is considered to reflect, to the same degree, in a reciprocal manner, hepatic deiodinase type I activity (Danforth i Burger, 1989). Our investigations could confirm such relations since in the present study, $\mathrm{rT}_{3}$ was directly related to C18:1, C18:2 and C20:4 acid intakes, whereas under the same conditions, hepatic DI activity was negatively correlated with $\mathrm{C} 18: 1$ and C18:2 intakes (Lachowicz et al., 2008).

An effect of fat amount on plasma $\mathrm{T}_{4}$ concentrations was seen in groups $\mathrm{S}$ and R. However, in line with other reports (Otten et al., 1980; Vermaak et al., 1986), only in rats fed sunflower oil did the HF diet induce lower $T_{4}$ levels than in animals consuming the MF diet. The different relationship between plasma levels of fatty acids with $T_{3}$ concentration and with DI activity (Lachowicz et al., 2008) suggest that factors other than hepatic DI influenced the $\mathrm{T}_{3}$ variability seen in this study. Plasma concentrations of triiodothyronine and free $\mathrm{T}_{4}$, but not total $\mathrm{T}_{4}$, were similarly related to plasma lipid metabolism indices. Their correlations with the triglyceride concentration were the opposite of those observed with TPO activity (Lachowicz et al., 2008). The direct relationship between free $\mathrm{T}_{4}$ levels and plasma concentrations of oleic, arachidonic and linoleic acid found here may be explained by competition between $\mathrm{T}_{4}$ and arachidonic acid in binding to transthyretin and thyroid hormone binding globulin, which are also found in humans (Lim et al., 1995).

The results reflect the complexity of the effects of fatty acids on plasma thyroid hormone levels. It seems that MUFA intake with rape seed oil might have induced lower $\mathrm{T}_{4}$ and higher $\mathrm{fT}$, with no effect on $\mathrm{T}_{3}$ concentration compared with the palm oil-fed groups. In contrast to this, high-fat diets rich in n-6 PUFA might have had a similar effect on $\mathrm{T}_{3}$ and $\mathrm{T}_{4}$ levels. Unsaturated fatty acids could have altered the thyroid hormone plasma profile secondary to their impact on peripheral enzyme pathways, as well as by competing with thyroid hormones in binding to plasma proteins. 


\section{REFERENCES}

Ahmed O.M., El-Gareib A.W., El-Bakry A.M., El-Tawab S.M.A., Ahmed R.G., 2008. Thyroid hormones states and brain development interactions. Int. J. Dev. Neurosci. 26, 147-209

Alrefai H., Allababidi H., Levy S., Levy J., 2002. The endocrine system in diabetes Mellitus. Endocrine 18, 105-119

Biondi B., Klein I., 2004. Hypothyroidism as a risk factor for cardiovascular disease. Endocrine 24, $1-13$

Clandinin M.T., Claerhout D.L., Lien E.L., 1998. Docosahexaenoic acid increases thyroidstimulating hormone concentration in male and adrenal corticotrophic hormone concentration in female weanling rats. J. Nutr. 128, 1257-1261

Clément K., Viguerie N., Diehl M., Alizadeh A., Barbe P., Thalamas C., Storey J.D., Brown P.O., Barsh G.S., Langin D., 2002. In vivo regulation of human skeletal muscle gene expression by thyroid hormone. Genome Res. 12, 281-291

Danforth E., Burger A., 1989. The impact of nutrition on thyroid hormone physiology and action. Annu. Rev. Nutr. 9, 201-227

Feng X., Jiang Y., Meltzer P., Yen P.M., 2000. Thyroid hormone regulation of hepatic genes in vivo detected by complementary DNA microarray. Mol. Endocrinol. 14, 947-955

Gronowska-Senger A., Pierzynowska J., 2002. Biological Food Evaluation (in Polish). SGGW Press, Warsaw, pp. 10-11

Kahl S., Rosebrough R.W., Elsasser T.H., 1998. Hepatic iodothyronine 5'-monodeiodinase activity in the broiler chicken: effect of dietary fat and triiodothyronine $\left(\mathrm{T}_{3}\right)$ supplementation. Nutr. Res. $18,1039-1047$

Köhrle J., 2007. Thyriod hormone transporters in health and disease: advances in thyroid hormone deiodination. Best. Pract. Res. Cl. En. 21, 173-191

Kopp W., 2004. Nutrition, evaluation and thyroid hormone levels - a link to iodine deficiency disorders? Med. Hypotheses 62, 871-875

Krotkiewski M., 2002. Thyroid hormones in the pathogenesis and treatment of obesity. Eur. J. Pharmacol. 440, 85-98

Lachowicz K., Koszela-Piotrowska I., Rosołowska-Huszcz D., 2008. Thyroid hormone metabolism may depend on dietary fat. J. Anim. Feed Sci. 17, 110-119

Lakatos P., 2003. Thyroid hormones: beneficial or deleterious for bone? Calcif. Tissue Int. 73, 205209

Lim C.F., Munro S., Wynne K., Topliss D., Stockigt J., 1995. Influence of nonesterified fatty acids and lysolecithins on thyroxine binding to thyroxine-binding globulin and transthyretin. Thyroid $5,319-324$

Lin S.-Y., Wang Y.-Y., Liu P.-H., Lai W.-A., Sheu W.H.-H., 2005. Lower serum free thyroxine levels associated with metabolic syndrome in Chinese population. Metabolism 54, 1524-1528

Mastorakos G., Karoutsou E.I., Mizamtsidi M., Creatsas R., 2007. The menace of disruptors on thyroid hormone physiology and their impact on intrauterine development. Endocrine 31, 219237

Oetting A., Yen P., 2007. New insights into thyroid hormone action. Best. Pract. Res. Cl. En. 21, 193-208

Otten M.H., Hennemann G., Docter R., Visser T.J., 1980. The role of dietary fat in peripheral thyroid hormone metabolism. Metabolism 29, 930-935

Rooyackers O.E., Sreekumaran N.K., 1997. Hormonal regulation of human muscle protein metabolism. Annu. Rev. Nutr. 17, 457-485 
Takeuchi H., Matsuo T., Tokuyama K., Suzuki M., 1995. Serum triiodothyronine concentration and $\mathrm{Na}^{+}, \mathrm{K}^{+}$-ATPase activity in liver and skeletal muscle are influenced by dietary fat type in rats. J. Nutr. 125, 2364-2369

Tsuboyama-Kasaoka N., Takahashi M., Kim H., 1999. Up-regulation of liver uncoupling protein-2 mRNA by either fish oil feeding or fibrate administration in mice. Biochem. Biophys. Res. Commun. 257, 879-885

Vermaak W.J., Kalk W.J., Kuyl J.M., Smit A.M., 1986. Fatty acid induced changes in circulating total and free thyroid hormones: in vitro effects and methodological artefacts. J. Endocrinol. Invest. 9, 121-126

Yamamoto N., Li Q.L., Mita S., Morisawa S., Inoue A., 2001. Inhibition of thyroid hormone binding to the nuclear receptor mobilization of free fatty acids. Hormone Metab. Res. 33, 131-137

Yen P.M., 2001. Physiological and molecular basis of thyroid hormone action. Physiol. Rev. 81, 1097-1142 